\title{
Transformation of Value System Due to International Integration. A Sociological Analysis Conducted at University of Sargodha
}

\author{
Sajida Jabbar \\ Dr. Ghulam Yasin \\ Umair Ahmed \\ Asad Umair \\ Department of Sociology, University of Sargodha
}

\section{Doi:10.5901/mjss.2014.v5n16p552}

\begin{abstract}
The present study helps us to reveal that how global cultural integration, electronic media, technology and global communication, affect on transforming the value system. Values are considered central for human being socialization and development but these values are changing very rapidly due to the process of global cultural integration. There are vagueness, disbeliefs, and suspicions due to these changes, particularly in the consciousness of youth and also losing their identity. The current state of global integration is causing imbalance in the proportion of the common concept of values. The present study aims to provide the sociological analysis of the transforming value system and their effects on Pakistani society. The major purposes of the study were to look at at the major factors that are responsible for the changing the value system and its implication on the society due to rapid development of cross border interaction among human societies. Quantitative method of research was applied. A sample of 150 students was selected by applying multi stage sampling techniques (Stratified and simple Random sampling) from different departments of University of Sargodha. Self administered questionnaire was used for the collection of data. Findings of the study depicted that the existing value system is transforming through the process of global cultural integration and electronic media where the elders respect has been decreased, love marriages are on the increased, children negotiate with their parents, changes in the sentiments of collectivism and individualism is in the fashion in society.
\end{abstract}

Keywords: International integration and globalization, Value transformation, Youth in Pakistan, Global media.

\section{Introduction}

The global integration can be defined as cross border interaction among human societies. This international interaction has widened because of information communication technology and media. Global cultural integration refers to the process to which particular beliefs and values that are mostly shared in the whole planet by means of the information communication technologies. In this way information communication technology and mass media are significant in promoting international cultural values all over the world (Castells, 2009). When people interact globally through Information Communication Technology it creates an alarming situation to the nations by the expanding international market that erode their autonomy and command over others. In other words, global cultural integrity is involved in expanding consumerism that is the beneficial for the western society and also promotes the western values and western ideology throughout the world (Held and McGrew, 1999).

Global cultural integration is a state of affairs whereby, one culture consciously adopts the worldwide ideas of another culture in terms of either manufacturing or utilization. It can also be argued that material and non material aspects of culture are associated with each other. Material cultural aspects are those that are tangible in the society like, cable television, cars, machinery, tools, computers and airplanes etc. While non material cultural aspects are norms, values, ideas, thoughts and opinions. Both the aspects influence each other in international integration process For instance, it is the culture that clarify what there will be eating pattern, dressing pattern and behaving pattern and consequently these patterns shape the cultural norms and values; as people are using worldwide products and also inclined toward western ideas and concepts ( Heckmann and Schnapper,2003). Global integration expanded through media and the target group that is youth because they accept more quickly global trends. They are most engaged with the world through media like movies, talk shows, news channels and social networking due to this linkage they accept global trends more and more as 
compared to other aged group this is why the focus of media is youth. Youth are more inclined to bring about changes in their behaviour. The same holds true for the majority of Pakistani youth. There are 83 million populations of youth in Pakistan; round about half of them are 15-29 years age categories (Qamar, et al. 2010).

The impact of global cultural integration on the changing value system is very intense and deep rooted. These changing values are creating ambiguity and doubts, especially in the minds of the younger generation. The value system changes through the procedure of international cultural integration and media communication and ultimately reshaping our family structure where respectful children changes to negotiation and family size also contracts. The freedom of choice, increasing materialism in society, blind imitation of Indian and western culture and changing family structure (Rothenberg and Laurence, 2003).

Global cultural integration multiplies around the globe and influences the communities, and pre-existing values. Values changing very rapidly like religious values, family values and work place values. Modernity and global cultural integration decreases social solidarity, integrity and increases individualism in society. Global interaction among human societies brings about changes in cooperative sentiments or collectivism and leads towards self centered individuals and advertises oriented culture of western society (Ritzer, 2008).

Positive aspects of global cultural integration are sameness of cultural patterns, business improvement, easy communication and technological development, political (weakens power of authoritarian governments), economic (jobs, capital, more choices for consumers), cultural (offers exposure to other culture).But on the other hand, global integration also have negative aspects e.g. loss of identity, self centralized individuals, rise of sub-culture and loss of traditional value system by the modern ones (Shobha, 2006). Modernization is another factor or tool for transforming the value system in every society. In underdeveloped countries like Pakistan, this modern term is associated with well educated and well off people. It has transformed the whole structure of people's lives like dressing patterns, food patterns, language, life styles, ideas, thinking and leisure time activities and so on. The liberalism and materialism is the outcome of modernization and play very important role in diminishing the traditional value system in society (McDonald, 1995).

Modernization directly affects the value system, because it is based on the western ideology. The most important goal of modernization is to put back religious fundamental thoughts, ideas and traditional web of social relations with modern ideology. Freedoms of speech and appearance have greater influence on transforming the value system of society (Cohon, 2011).

\section{Significant of the Study}

The present research aims at evaluating the influence of global cultural integration on the transforming the value system of youth. International integration affects all areas of life. It has changed the whole world into a global village. Under the influence of global cultural integration, openness to change, information coming from the media, and contact with other cultures have become much easier than ever before and consequently traditional values are changing. Although global cultural interaction has increased personal choices and youth has easy access to new technologies and media due to which values and attitude of youth is changing very rapidly. But the trend of modern values and many other aspects of global integration are destroying the local values and local patterns of Pakistani society.

The change agents such as international integration, modernization, industrialization, western brands, MNCs and electronic media attacks on our traditional beliefs, formed habits, religious fundamental ideas, social norms, political ideologies as well as cultural and educational heritage of Pakistani society. As a result of these factors our traditional value system is replacing by the modern one.

\section{Objectives}

The objectives of the present study are,

1. To find out the influence of international integration on transforming the value system of youth.

2. To find out the influence of media on losing the intensity of traditional value system of youth.

3. To find out the impact of technology on transforming the value system of youth.

4. To find out the impact of global communication on changing the value system of youth.

5. To find out the implications of changing values on lifestyle.

\section{Literature Review}

Cohon (2011) says that global cultural integration can be considered as highly developed stage in expansion of western 
culture and civilization. It means western thoughts, western institutions, and their approach to diverse life's aspects, and promotion of western culture, that is frequently on the expense of other cultures. In fact international integration produces homogeneity all over the world where children are going to grow up like western people by adopting their values. Now they prefer to eat big Macs, buy western brands like Nikes and blue jeans, and like modern music according to worldwide culture.

The Jews and $1^{\text {st }}$ world countries hold their special interests in sabotaging the traditional value system of Muslim countries.

Wellman and Wortly (1989) accomplished that the children can provide the sufficient support to their parents at their old age. But due to many changing the children are going away from their traditional value system. They are becoming more materialistic and their relationship with their parents becomes weak and feeble. This is more outcome of youth integration with modern value system. There are more ties between sibling than between parents and children and they provide the considerable support. If the relationship network is really strong then the generation gap between parents and children become extinct.

Scholte (2000) says that due to internet all kinds of institutions in Pakistan are facing troubles and difficulty because people do not know what the internet is and what is www; they only know that they can watch movies, used face book and porn videos by using net. Most of the people used internet just for the purpose of blue entertainment. Because it is very easy to access these types of videos, the uploading method of these videos and images whenever and whatever a person wants. The sites are easily available at net like Youtube.com. Easily available and low-cost technology making the situation so alarming that people use any cheap prostitute and make a porn clip and upload that clip in few dollars at any western porno site. This type of business is very common in big cities of Pakistan like Lahore, Karachi and Islamabad. This is a very sad fact that most of the people search on the internet only for Pakistani porn videos.

Bengston (1991) completed that family integration revolves around certain values and these values are collectivism, cooperation, hospitality, respecting elders, sacrifices and religious integration. But these values are shifting with the passage of time. Materialism that is the very important factor changing these traditional values to the modern ideologies.

Rummens (1993) argued that the basic traditional values are losing their power with the trend of global cultural integration. These values are the most important, because of giving national identity to the people. Instead of blaming cultural sameness, the author argues that globalization of American foodstuff chains like KFC in Asia has led to a decline in local food and promotion of western food products in all regions of the world.

Shrof (2004) stated that the systematic and modern means of knowledge are very efficient and fast, we can find information and valid knowledge by using the internet, but there are many negative ways of getting such as people gain knowledge in a more personal way and becoming more rational that eventually break up much of contact with the society and move them toward more material gains. This view has been heralded by a psychologist vey long ago; culture is deteriorating slowly. "Modern man is feeling more instability with himself, with his fellow beings, with society and with the world in which he or she is living. He acts just like a commodity, become a profit seeker and wants to earn more and more.

Castells (1996) argues although global interaction among human societies provides up to date information but it is a threat for local culture, religious and family values. In this regard the argument is of utmost importance that 'Our lives and our natural world are transformed by the contradictory trends of global integration. Cultural values are adversely affected by the influences of global communication because the multi dimensional effects of global interaction and modernization have transformed the whole fabric of the community, family, and religious values.

Telo, et al. (2004) accomplished that global cultural integration affects the deep rooted value system of Pakistani society. Ideas of right and wrong, kindness and evil, materialism and individualism, social separation from nature and diminishing social solidarity all are distorted by international integration, mass media and worldwide markets. Therefore traditional customs, values and local languages are declining very swiftly with the arrival of worldwide integration process.

Muzaffar (2002) admits that religious values are adversely affected by the global cultural integration. Secularism is in practise throughout the world because of modernization where the religious practices and values are on the decline, for example Pashtu society is considered as fundamentalist and conventional type of society, but these features are declining, formality has been increased and religious values are becoming weak. Moreover, they have formed their own sects and considered religion as a secondary preference, therefore reducing the religious tolerance and promoting religious conflicting issues.

Shrinivas (2005) depicts the important effects of electronic media on youth. Modern way of life as controlled by media adversely affects the lives of youth by reshaping their preference of way of dressing, eating, popular music, where to be seen, and what options to accept and so on. Hollywood movies, MTV licence of Bombay-based, and Hong Kong 
based TV plays very vital role in bringing new cultural patterns that are favourable to youth. Media promoting these trends deliberately among youth, like worldwide markets and consumer culture and youth feel proud with more and more consumption. The electronic media has changed the whole fabric of their lives including their norms, values, behaviour, preferences, ideas and thinking etc.

Wakil (1981) said that it is the time in the family life cycle when it is particularly difficult for young people, parents and other adults to understand each other. The children sometimes feel that their parents are inflexible and their socialization is not appropriate. With the decreasing of traditional social control the popular culture increased among youth. The life of youth shaped according to the media promoted culture because it was popular and attractive for the youth. In this regarding parents had no control on the youth in their choices. So there must be some essential modifications in other important values and ideals.

\section{Research Methodology}

Sound methodology is very important in order to create a chain for knowledge and empirical verification of hypothesis (Nachmias and Nachmias D, 1992). The purpose of this section is to give the details of techniques and tools to be employed for conducting the study. Research based on the systematic methodology that is structured means it consists of explicit rules and procedures.

Quantitative research design was used for the present study. The universe of this research including both male and female from different departments of University of Sargodha. The population of this study consist of the group concerning whom the researcher desires to construct conclusion (Ume Sekaran, 2010). The main objective of selecting educated and youth population was that they adopt more changes as compared to other age group people. 150 respondents as a sample were taken by using stratified sampling method. The reason of stratified sampling is to make the research most representative in this regard the population is divided into sub groups or strata (L. R. Gay, 9th Edition).

In this consideration the researcher selects 10 social science departments through simple random method out of two major stratums I.e. Natural and Social science departments and then an average of 15 students were taken from each department. Data was collected by using self administered questionnaire. Questions were divided into 5 major sections, in the $1^{\text {st }}$ step it is asked about the socio-economic and demographic characteristics of the respondents, and the other 4 sections were about other information that researcher required for the present study. Likert scale was used in the research, there were 5 options in each question that are strongly agree, agree, neutral, disagree, strongly disagree. Data was analyzed by using SPSS 16.0. In order to check association between dependent and independent variables Chisquare test was applied.

\section{Results and Discussion}

Table 4.1: Percentage distribution of respondents regarding their responses that internet has negative impact on our cultural values due to pornographic material.

\begin{tabular}{|c|c|c|}
\hline Responses & Frequency & Percent \\
\hline Yes & 112 & 74.7 \\
\hline No & 38 & 25.3 \\
\hline Total & 150 & 100.0 \\
\hline
\end{tabular}

Table no 4.1 depicts the views of the respondents about the use of internet that has a negative impact on our cultural values due to pornographic or immoral material. Thus $74.7 \%$ respondents agree that internet has a negative impact on our cultural values and transforming the value system of youth.

Omekwu (2006) says that the Internet collapses the minds and ideology of people. This is also bringing the drastic changing in morality and ethical values. The negative effect of ICT is that it is promoting western culture among youth through internet cable and movies. Media is promoting horrible videos, pornography, child abuse and international terrorism and making the situation worst for traditional societies. Most of the people used internet only for the purpose of blue entertainment and immoral communication. Media is taking away youth from the traditional culture and value system, their modes of behaviour, dressing pattern, eating habits are changing very rapidly and their interaction patterns are also going to be changed. In this regard youth like to wear such a dress that showed their body shape very clearly. In addition it is also becoming the major cause of drug abuse, and other negative life style like, pornography, use of arms and ammunitions. Therefore, native languages and native morals are increasingly becoming extinct. 
Table 4.2: Percentage distribution of respondents regarding their responses that electronic media decreases the importance of arrange marriages.

\begin{tabular}{|c|c|c|}
\hline Responses & 'Frequency & Percent \\
\hline Yes & 113 & 75.3 \\
\hline No & 37 & 24.7 \\
\hline Total & 150 & 100.0 \\
\hline
\end{tabular}

The above mentioned table states that the electronic media decreases the importance of arrange marriages. Thus $75.3 \%$ respondents agree that the electronic media decreases the importance of arrange marriages. Scholte (2000) says that cable television is the strongest change agent that transforms the indigenous value system of youth. Most of the studies have revealed the fact that media is deteriorating the moral values of youth who just for the sake of becoming unique and prominent in fact reject the adult authority. Many young respondents had a private television or cable in their homes. In this way they can see anything without the interference of their parents. This particularly has transformed our family norms including the traditional family is declining, nuclear family is in trend, marriage patterns are also going to be changed and youth prefer to choose their own spouse according to their own will. But in relationship they are still extended and consult with each other while making a decision in their lives.

Table 4.3: Percentage distribution of respondents regarding their responses that the global communication has made our world smaller.

\begin{tabular}{|c|c|c|}
\hline Responses & Frequency & Percent \\
\hline Yes & 122 & 81.3 \\
\hline No & 28 & 18.7 \\
\hline Total & 150 & 100.0 \\
\hline
\end{tabular}

The above mentioned table shows the opinion that $81.3 \%$ respondents agree that the global communication has made our world smaller. Tasawur et al. (2001) stated that global cultural integration has decreased worldwide boundaries and making the world smaller than ever before. In fact global culture integration has transformed the whole world into a 'global village' where people are more attached and connected with each other. Information and money are flowing very efficiently and rapidly across the globe and people have easy access toward goods and services formed in different countries.

When people communicate globally through Information Communication Technology it creates dangerous conditions by creating worldwide markets that eliminate independence and domination of countries. In other words, global cultural integrity is influential in creating consumer culture that assists the western world system and also promotes the western values, western thoughts and western ideology (Held and McGrew, 1999).

Table 4.4: Percentage distribution of respondent regarding their responses that by watching Indian dramas their native language is diminishing.

\begin{tabular}{|c|c|c|}
\hline Responses & Frequency & Percent \\
\hline Strongly agree & 42 & 28.0 \\
\hline Agree & 54 & 36.0 \\
\hline Neither agree nor disagree & 29 & 19.3 \\
\hline Disagree & 20 & 13.3 \\
\hline Strongly disagree & 5 & 3.3 \\
\hline Total & 150 & 100.0 \\
\hline
\end{tabular}

The above mentioned table represents that the $28.0 \%$ respondents strongly agree that by watching Indian dramas their native language is diminishing,36.0\% respondents agree with the statement that by watching Indian dramas their native language is diminishing, while 19.3\% respondents neither Agree nor Disagree that by watching Indian dramas their native language is diminishing, $13.3 \%$ respondents disagree that by watching Indian dramas their native language is diminishing, and 3.3\% respondents strongly disagree that by watching Indian dramas their native language is diminishing.

Bala (1986) stated that cross border interaction among human societies brought massive changes in family 
institution as joint family system is replaced by nuclear family system. The major reason for the failure of joint family system is that youth are shifting from rural to urban areas in search of employment opportunities that make the family bindings limited. Old age homes and nursing homes are working for old people and new employment opportunities are increasing as care givers are required to look after the old age people in those homes. Youth are not emotionally attached with their grandparents and they feel loneliness. Family size is going to be decreased. With the advent of globalization because both the parents work outside of the home parental interaction and authority is also declined.

Table 4.5: Percentage distribution of respondent regarding their responses that the environment of university has changed the eating habit of students.

\begin{tabular}{|c|c|c|}
\hline Responses & Frequency & Percent \\
\hline Strongly agree & 38 & 25.3 \\
\hline Agree & 67 & 44.7 \\
\hline Neither agree nor disagree & 20 & 13.3 \\
\hline Disagree & 19 & 12.7 \\
\hline Strongly disagree & 6 & 4.0 \\
\hline Total & 150 & 100.0 \\
\hline
\end{tabular}

The table indicates that $25.3 \%$ respondents strongly agree that the environment of university has changed the eating habits of students, $44.7 \%$ respondents agree that the environment of university has changed the eating habits of students , while 13.3\% respondents neither Agree nor Disagree with the statement that the environment of university has changed the eating habits of students, $12.7 \%$ respondents disagree that the environment of university has changed the eating habits of students, and $4.0 \%$ respondents strongly disagree that the environment of university has changed the eating habits of students.

Cohon (2011) says that global cultural integration should be viewed as a complex phase in the spread and expansion of western culture. That means the influence of western institutions, western ideas, western thoughts and western approaches on each and every component of society. The western culture is becoming popular and traditional culture is going to be dispersed. One of the most important arguments of global integration is that it creates such culture that is homogenous across the globe and promoting western brands .Now youth prefer to eat KFC pizza burger, wear blue jeans and like to spend their vacations at Disney World. Youth feel more proud when they buy imported goods and feel satisfied with western brands.

\section{Testing OF Hypotheses}

\subsection{Hypothesis 1}

"The more the exposure towards media, the higher will be the trend among youth to dress up in western style."

"Media exposure does not influence on the youth trend to dress up in western style."

\begin{tabular}{|c|c|c|c|c|}
\hline $\begin{array}{c}\text { Cross Tabulation between the Variables "Spending Time on Watching TV and Student's Trend Toward Western Brands" } \\
\text { I spend most of my time on watching TV. }\end{array}$ & \multicolumn{2}{|c|}{ Students feel more proud when they buy western brands. } \\
\hline & To greater extent & To some extent & Not at all \\
\hline To greater extent & 42 & 10 & 10 & 62 \\
\hline To some extent & 10 & 42 & 6 & 58 \\
\hline Not at all & 8 & 9 & 13 & 30 \\
\hline Total & 60 & 61 & 29 & 150 \\
\hline
\end{tabular}

Chi square: 56.857 Degree of freedom: 4 P value: $000^{\star \star}$ Level of significance: 0.005

\subsection{Discussion}

Shobha (2008) says that Pakistani culture is a unique and distinctive kind of culture because it has preserved the long established value system of society throughout many years of history. But now due to IT revolution western culture is widespread. Today people are using western brands. In Pakistan almost 11.5 million people are using technology and it is very much clear from the study that they are employing technology just for their own preferences . Now they are more indulge in outdoor activities than ever before, reading newspapers, magazines, books and spending less time with their 
families hence promoting individual characteristics and they are less integrated. The generation gap between parents and children is increasing. This generation gap starts when parents enforce their fixed value system on their children. The researcher concluded that this clash can become weak if parents realize that children have their own desires and wishes and they have to keep pace with the modern world.

Chi-square value (56.857) shows a highly significant $\left(P=.000^{\star \star}\right)$ association between transformation of value system and using western brands, and the alternative hypothesis is accepted. Thus the difference between the observed frequencies and expected frequencies was very large, so the null hypothesis was rejected.

\subsection{Hypothesis 2}

"The more the use of technology the more will be the family ties weakened".

"Technology has not weakened the family ties".

\begin{tabular}{|c|c|c|c|c|}
\hline $\begin{array}{r}\text { Cross Tabulation between the Variables "Mobile Phon } \\
\text { their Parent }\end{array}$ & $\begin{array}{l}\text { ened Family Ties } \\
\text { omes". }\end{array}$ & nd Youth Pref & ences $t$ & \\
\hline Mobile phones have weakened family ties. & Youth prefer to & $\begin{array}{l}\text { keep their parent } \\
\text { homes. }\end{array}$ & s in old & Total \\
\hline & To greater extent & To some extent & Not at all & \\
\hline To greater extent & 35 & 19 & 12 & 66 \\
\hline To some extent & 14 & 39 & 6 & 59 \\
\hline Not at all & 8 & 7 & 10 & 25 \\
\hline Total & 57 & 65 & 28 & 150 \\
\hline
\end{tabular}

Chi square: 27.345 Degree of freedom: 4 P value: $0.000^{\star \star}$ Level of significance: 0.005

\subsection{Discussion}

Troll (1982) argues that parents feel being alone because of less communication with their children. The care giving values and elders respect and authority decreases with the passage of time. Now the children prefer to place their parents in the old age homes. Although there is evidence that the relation of parents and children are important to both of them but when the children reach teenage years then transforms their firm traditional values and causes a gap between both parents and children. As a result of this family ties becomes fragile.

The hypothesis of the research depicts an association between the effects of value change on the lifestyle of people and its effects on family members. The calculated value is greater than the tabulated value, so the alternative hypothesis is true. The value of chi square is 27.345 while the $p$ value is $0.000^{\star *}$. The difference between the observed frequencies and expected frequencies was very large and therefore null hypothesis was rejected. The other change agent is global integration that is responsible for value transformation in the society. The trend of the family is shifting from joint to nuclear family. On the other hand the children prefer to live separately from their parents due to different ideologies and thoughts. Therefore many old age homes have been established. Media has changed the mentality of youth and thus the family ties are deteriorating which is destructive for family members.

\subsection{Hypothesis 3}

"If the higher access toward technology then it will make people less religious".

"Technology does not make people less religious".

$\begin{aligned} & \text { Cross Tabulation between the Variables "Student's Access to Mobile Phones and They are Becoming Less Religious Due } \\
& \text { to Technology". }\end{aligned}$
\begin{tabular}{|c|c|c|c|c|} 
I \\
I have easy access to mobile phone. & To greater extent & To some extent & Not at all \\
\hline To greater extent & 38 & 21 & 10 & 69 \\
\hline To some extent & 12 & 28 & 7 & 57 \\
\hline Not at all & 8 & 6 & 10 & 24 \\
\hline Total & 58 & 65 & 27 & 150 \\
\hline
\end{tabular}

Chi square: 30.201 Degree of freedom: 4 P value: $0.000^{\star *}$ Level of significance: 0.005 


\section{Discussion}

Traditional value system stresses on the emotional web of social relations and collectivism. On the other hand it promotes cultural, social and religious integration. Because of information communication technology our traditional values are replaced by the modern ones so people are becoming less religious. Higher exposure of electronic media invites western styles of living and growing liberalism.

Kamal Mohammad (2003) reveals that ICT has brought Western culture and way of life to the East and to the rest of the world. Through global integration secularism performed by the West has also reached the homes and minds of the people in the East, destroying their Islamic and Eastern family core-values. Secularism is a way of life separates things and actions into two-all that belongs to God and all that belongs to the state. The two states of matter cannot mix up. The dichotomy that is spread in their everyday life gives people in the West to think of God only when they are in the places of worship and when they are elsewhere, they can behave and do anything that suit their self-centred wishes, and this is owing to technology. Such a philosophy of life is very contrasting and conflicting to the Islamic and Eastern life style where people much emotionally involved to their religious beliefs. Obsession for American lifestyle in terms of their fast food like KFC and McDonald and other items like clothing, music and movies are changing the cultural values of people and making them less religious.

The researcher assumes the relationship between two variables (changing value system and the exposure of electronic media). The calculated value is greater than the tabulated value, so the alternative hypothesis was true. The value of the chi square is 30.201 and $p$ value is $.000^{* *}$.

There was difference between the observed and expected frequencies and therefore null hypothesis is rejected and alternative hypothesis was accepted.

\section{Conclusion}

The researcher concluded that the traditional values system of Pakistani society is changing due to international integration. Many factors are accountable for that. These factors are technological advancement, western brands, international integration, MNCs, innovations and electronic media. The most important factor for value change in societies is global cultural integration, the cross border interaction among human societies. Our traditional values are replacing by the modern values. In addition to this materialism in society invites the people to throw away their traditional values and accept modern values and modern life styles that allow them to express their freedom of expression. Electronic media (a major change agent) has changed the way of thinking of youth to be engaged in modern patterns of life.

Global integration provides various directions to Muslim world countries. This is mainly factual in case of Information Communication Technology and cable television. Our traditional values are losing their strength due to worldwide spread of electronic and print media. Because of these cultural changing, youth are confronting many difficulties concerning the transformation of value system. A small part of well-educated people of traditional communities understand the importance of traditional values. It involves participation in the local culture and preserving traditional values, especially family and religious values, while, at the same time, adopting the universal cultural code and participating in worldwide culture.

\section{Recommendations}

- People must inculcate Islamic values and also act upon accordingly.

- Electronic media should support our cultural values and traditional norms.

- Media has significant role in changing minds of people.

- Government must prohibit Western programmes movies and Indians dramas.

- People must have the consciousness about their own culture to future generation.

- People must groom their children according to traditional norms and religious values.

- People need to control the influence of other cultures through media, tourism and education of people.

- The parents should not implement their thoughts and guidance about their children. They must be realizing that after all children have their own judgments and desires and they must keep pace with the modern world. 


\section{References}

Bala, Raja.(1986). Trends in Urbanization in India 1901-1981. Rawat Publication: Jaipur.

Bengtson, V.L., Robert, R.E.L. (1991). "Generation Gap and its Impacts." Journal of Marriage and the Family, Vol.53, No.4, pp.856-870. Castells, M. (2009). Communication Power. New York: Oxford University Press.

Cohon, S.P.( 2011). "The Future of Pakistan." The Brookings Institution, Massachusetts Aveneu,Washington,DC.

Castells, M. (1996). The rise of network the society. Oxford: Blackwell Publishing.

Heckmann and Schnapper (2003) The Integration of Immigrants in European Societies.

Held, D. and McGrew, A. (1999). Global Transformations: Politics, Economics and Culture.Cambridge:Polity. Transition, pp. 38-46.

Kamal Mohamed.( 2003). Globalisation and the new realities. Subang Jaya,Malaysia: Pelanduk Publications (M) Sdn. Bhd.

McDonald, P.( 1995). "Australian Families: Values and Behavior." in R. Hartley (ed.) Families and Cultural Diversity in Australia Allen \& Unwin,Sydney.

Mohamed, M.,( 2002). Globalisation and the new realities. Subang Jaya,Malaysia: Pelanduk Publications (M) Sdn. Bhd.

Nachmias, C. F. And Nachmias .D, (1992) "Research methods in social science."Fourth edition.Edward Arnold.A division of Hodder and Stoughton .

Omekwu, C. (2006). African culture and libraries: the information technology challenge. The Electronic Library, 24(2), $243-264$.

Qamar, S, Umrani, S, Fatima, S, and Bashir, T, (April 2010). "Symposium at Peshawar". ASK Development Newsletter. Lahore, Pakistan.

Ritzer, G. (2008). Sociological Theory. New York, NY: McGraw-Hill.

Rothenberg, Laurence. E. (2003). Globalization 101: Three tensions of Globalization. The American Forum for Global Education, NY No. 176.

Rummens, J.( 1993). "Personal Identity and Social Structure in Sint Maartin/Saint Martin: a Plural Identities Approach." Unpublished Thesis/Dissertation: York University.

Scholte, J. A. (2000). Globalization: A critical introduction. New York: St. Martin'sPress.

Shobha, M. (2006)."Globalization and its Impact on Families." 4th Viennese Conference on Mediation Vienna, Austria."

Shobha ,P. (2008). Globalization and its impact on families. Retrieved on Augest28, 2008 from World Wide.

Tasawur T.A. Iqbal.(2001): his vision of a Muslim home land. "Iqbal studies and Pakistan news papers/.- Lahore: Bazm-e-Iqbal, (N.D) pp, $1-5$.

Telo, Mario. (ed). (2001) European Union and New Regionalism: Regional Actors and Global Governance in a Post-hegemonic Era. Aldershot, England; Burlington, VT: Ashgate.

Troll, L.E. (1982). "Family Life in the Middle and Old Age: The Generation Gap."Annuals of the American Acadamy of Political and Social Science, Vol. 646, Middle and Later Life

Ume Sekaran, R. B. (2010). Research Methods for Business.

Wakil, S. P., Siddique, C. M. . Wakil, F.A. 1981. "Between Two Cultures: A Study in Socialization of Children of Immigrants." Journal of Marriage and Family, Vol.43, No.4, pp.929-940.

Wellman, B., Wortly. S. (1989). "Brother Keepers: Situating Kinship Relations in Broader Network of Social Support." Sociological Perspectives, Vol.32, No.3, pp.273-306. 